Bangladesh J. Bot. 38(2): 163-169, 2009 (December)

\title{
EFFECTS OF NITROGEN ON YIELD AND CHLOROPHYLL OF POTATO (SOLANUM TUBEROSUM L.) CULTIVARS
}

\author{
SEMIHA GÜLER* \\ Black Sea Agricultural Research Institute, 55001 Samsun, Turkey
}

Key words: Potato, Solanum tuberosum L., Leaf chlorophyll, Nitrogen, Yield

\begin{abstract}
Effects of nitrogen on the leaf chlorophyll (chl), yield and yield attributing characters of potato as tuber number and mean tuber weight were studied. Correlation coefficients between the investigated characters were determined. Five nitrogen rates (0, 150, 200, 250 and $300 \mathrm{~kg} / \mathrm{ha}$ ) and four potato cultivars (Burren, Slaney, Anna and Emma) were used in the study. First, second, third class tuber yields and total tuber yield, tuber number per plant, and leaf chl were significantly influenced by both nitrogen rate and cultivar, whereas mean tuber weight was affected only by cultivar. Maximum total yield was obtained at $200 \mathrm{~kg} \mathrm{~N} / \mathrm{ha}$. There was significant linear relationship between leaf chl and $N$ applied $\left(R^{2}=0.91\right)$. There were significant correlations between chl and yield and yield related characters. Total yield significantly correlated with leaf chl. Correlations between first class yield and total yield as well as total yield and tuber number per plant were highly significant.
\end{abstract}

\section{Introduction}

Nitrogen is of vital importance for plant growth due to being a part of amino acid, protein and chlorophyll molecule (Gilbert 1949, Tisdale and Nelson 1956). Potato needs large amount of nitrogen. Therefore, adequate $\mathrm{N}$ fertilization is critical for optimizing potato yield and quality (Westermann and Kleinkopf 1985, Westermann et al. 1988). Insufficient available $\mathrm{N}$ leads to reduced growth, reduced light interception, limited yield and early crop senescence. On the otherhand, excessive available $\mathrm{N}$ can result in reduced yield, delayed tuber set and reduced tuber dry matter content (Kleinkopf et al. 1981).

Chlorophyll meter (Minolta) uses light sources and detects the light transmitted by a plant leaf at two wavelengths (at red and infrared region of the spectrum). This has been used for determination of $\mathrm{N}$ requirements of many crops including corn (Piekielek et al. 1995, Blackmer and Schepers 1995, Varvel et al. 1997), wheat (Singh et al. 2002), rice (Turner and Jund 1991, Singh et al. 2002) and potato (Shaaban and El-Bendary 1999, Denuit et al. 2002). Yadava (1986) working with 22 species representing 14 plant families found significant correlations between chl meter reading and chl concentration determined by a conventional technique. Vos and Bom (1993) reported that chl meter reading was well correlated with laboratory measurements of chl content and with the nitrogen concentration in leaves of potato $\left(r^{2}>0.95\right)$. Wu et al. (2007) compared petiole nitrate concentrations, chl meter readings and satellite imagery to detect nitrogen status of potato canopies by applying six N rates from 34 to $270 \mathrm{~kg} / \mathrm{ha}$. They found that overall treatment variations in chl meter readings were consistent with those in petiole nitrate nitrogen $\left(\mathrm{NO}_{3}-\mathrm{N}\right)$ concentrations. Madeira et al. (2003) reported that in situ chl meter readings and extractable chl content were highly correlated with, both for chl $a\left(r^{2}=0.93\right)$ and total chl $\left(r^{2}=0.89\right)$.

The aims of the present study were to determine yield, yield attributes and leaf chl content of potato as influenced by nitrogen application on crop cultivars and to find out the relationships among these characters.

*E-mail: semihag@yahoo.com 


\section{Material and Methods}

The study was carried out at Ladik-Samsun, Turkey in 2006. Five N rates (0, 150, 200, 250 and $300 \mathrm{~kg} / \mathrm{ha}$ ) and four potato cultivars (Anna, Burren, Emma and Slaney) were used in the experiment. Anna (OP 4051/2 $\times$ Cara) produces a high yield of bright tubers suitable for prepacking. It shows very good storage ability and resistance to common scab and PCN. Burren (Marfona $\times$ Spunta) is a long-oval potato with shallow eyes, drought resistant and good storage ability. Emma (Colleen $\times$ Estima) combines earliness with good resistance to most common potato diseases. Having excellent taste, it is suitable for early baker production. Slaney (Maris Page $\times$ Cara) is a very efficient nutrient user allowing less fertiliser applications. It is good for boiling, steaming, baking and chipping.

Experimental site was above $950 \mathrm{~m}$ sea level. Mean, highest and lowest temperatures of the site were 9.5 - 36 (August), and $-17^{\circ} \mathrm{C}$ (January), respectively. Physical and chemical properties of experimental soil were (measured following the methods described in references given in parenthesis) texture loamy (Richards 1954), pH 7.4 (Jackson 1962), salinity 0.08\% (Richards 1954), organic matter 2.3\% (Chapman and Pratt 1961), $\mathrm{CaCO}_{3} 3.40 \%$ (determined by Scheibler calcimeter), potassium $308 \mathrm{~kg} /$ ha (Richards 1954), phosphorus $236 \mathrm{~kg} / \mathrm{ha}$ (Olsen 1954).

Experimental design was completely randomized block with three replications. Each plot was $22.4 \mathrm{~m}^{2}$. Inter row and inter plant spacing were 0.70 and $0.40 \mathrm{~m}$, respectively. Each cultivar had two rows having 10 plants in each. Data were collected from twenty plants for each cultivar. Calcium ammonium nitrate $(26 \% \mathrm{~N})$ was used as $\mathrm{N}$ source. In addition, all plots received $50 \mathrm{~kg} / \mathrm{ha}$ phosphorus and $150 \mathrm{~kg} / \mathrm{ha}$ potassium. Triple super phosphate and potassium sulphate were used as $\mathrm{P}$ and K sources, respectively. All N, P and K fertilizers were broadcasted and incorporated to the soil before sowing.

Potato seeds were sown on 2 May 2006. Tubers were harvested at the second week of September in 2006. Twenty plants for each cultivar were harvested. Tuber diameter was used for classification of tuber size. Tubers $>5.5 \mathrm{~cm}$ were classified as first class, between 5.5 to $3.5 \mathrm{~cm}$ as second class, and $<3.5 \mathrm{~cm}$ as third class. Tubers were counted for each plot. Tuber number per plant was calculated dividing the total number of tuber by the total number of plant in each plot. Mean tuber weight was calculated dividing the tuber yield by the number of tuber. Leaf chl was measured on 20 leaf samples by using SPAD chlorophyll meter (Minolta) at the flowering period of potato. Chl reading was taken two times in this period to see the changes in time. Analysis of variance was performed by using MSTAT program. LSD test was used for comparison of the mean values.

\section{Results and Discussion}

Tuber yield: Tuber yield of various classes such as first, second and third class, and total tuber yields of potato are presented in Table 1. Total tuber yield, first, second and third class tuber yields of potato were significantly affected by rate of nitrogen application and cultivars. Nitrogen $\times$ cultivar interaction was significant for total, second and third class tuber yield. Total tuber yield, and first, second and third class tuber yield of potato were increased with increasing $\mathrm{N}$ rates. These results are consistent with previous reports (Jenkins and Nelson 1992, Maier et al. 1994). Slaney and Anna cultivars produced the highest total tuber yield when compared to Burren and Emma cultivars. These results are also consistent with the previous findings (Kleinkopf et al. 1981, Saluzzo et al. 1999, Tekalign and Hammes 2005). When compared with nitrogen rate for total yield it was found that there was a yield increase up to $200 \mathrm{~kg} \mathrm{~N} / \mathrm{ha}$. 
Table 1. First, second and third class and total tuber yield (ton/ha) of potato.

\begin{tabular}{lccccc}
\hline Cultivars & \multicolumn{5}{c}{$\mathrm{N}(\mathrm{kg} / \mathrm{ha})$} \\
\cline { 2 - 5 } & 0 & 150 & 200 & 250 & 300 \\
\hline $1^{\text {st }}$ class yield & & & & \\
Burren & 3.71 & 3.62 & 5.73 & 5.90 & 6.19 \\
Slaney & 4.66 & 4.61 & 7.29 & 7.36 & 8.23 \\
Anna & 2.19 & 7.11 & 8.32 & 6.26 & 6.12 \\
Emma & 3.28 & 4.81 & 4.81 & 4.98 & 6.20 \\
Mean & $3.46 \mathrm{c}$ & $5.04 \mathrm{~b}$ & $6.54 \mathrm{ab}$ & $6.13 \mathrm{ab}$ & $6.69 \mathrm{a}$ \\
$2^{\text {nd }}$ class yield & & & & & \\
Burren & 1.07 & 2.43 & 2.31 & 2.28 & 2.14 \\
Slaney & 3.18 & 2.54 & 3.46 & 4.07 & 3.58 \\
Anna & 1.97 & 3.05 & 4.25 & 4.00 & 2.71 \\
Emma & 1.00 & 2.40 & 1.80 & 4.09 & 2.61 \\
Mean & $1.81 \mathrm{c}$ & $2.61 \mathrm{~b}$ & $2.96 \mathrm{~b}$ & $3.61 \mathrm{a}$ & $2.76 \mathrm{~b}$ \\
$3^{\text {rd }}$ class yield & & & & \\
Burren & 1.15 & 2.16 & 1.14 & 2.19 & 2.23 \\
Slaney & 2.48 & 2.57 & 2.36 & 3.11 & 3.57 \\
Anna & 1.58 & 3.23 & 4.94 & 2.66 & 3.76 \\
Emma & 1.08 & 1.63 & 1.73 & 1.05 & 2.88 \\
Mean & $1.57 \mathrm{c}$ & $2.39 \mathrm{abc}$ & $2.54 \mathrm{ab}$ & $2.25 \mathrm{bc}$ & $3.11 \mathrm{a}$ \\
Total yield & & & & 10.38 & 10.57 \\
Burren & 5.94 & 8.22 & 9.19 & 10.38 \\
Slaney & 10.33 & 9.74 & 13.15 & 14.55 & 15.38 \\
Anna & 5.75 & 13.41 & 17.52 & 12.94 & 12.59 \\
Emma & 5.36 & 8.85 & 8.35 & 10.13 & 11.70 \\
Mean & $6.85 \mathrm{c}$ & $10.06 \mathrm{~b}$ & $12.05 \mathrm{ab}$ & $11.99 \mathrm{ab}$ & $12.56 \mathrm{a}$ \\
\hline
\end{tabular}

Level of significance: First class yield: $\mathrm{N}(\mathrm{P}<0.01)$; cultivar $(\mathrm{P}<0.01)$; $\mathrm{N}$ vs cultivar $(\mathrm{P}>0.05)$; Second class yield: $\mathrm{N}$ $(\mathrm{P}<0.01)$; cultivar $(\mathrm{P}<0.01)$; $\mathrm{N}$ vs cultivar $(\mathrm{P}<0.01)$; Third class yield: $\mathrm{N}(\mathrm{P}<0.01)$; cultivar $(\mathrm{P}<0.01)$; $\mathrm{N}$ vs cultivar $(\mathrm{P}<0.05)$; Total yield: $\mathrm{N}(\mathrm{P}<0.01)$; cultivar $(\mathrm{P}<0.01)$; $\mathrm{N}$ vs cultivar $(\mathrm{P}<0.01)$

Mean tuber weight and tuber number per plant: Mean tuber weight and tuber number per plant are presented in Table 2. Mean tuber weight was increased with increasing $\mathrm{N}$ rate. It was lowest in control and highest in the $300 \mathrm{~kg} /$ ha nitrogen application. This finding is in agreement with the result of Maier et al. (1994). Tuber number per plant was significantly affected by $\mathrm{N}$ rate, cultivar and $\mathrm{N}$ rate $\times$ cultivar interaction. The lowest tuber number per plant was found in control. Other treatments were in the same statistical group in terms of tuber number. Slaney and Anna cultivars had the highest tuber number per plant whereas Burren and Emma had the lowest. From this finding it can be concluded that yield differences among were due to differences in tuber number per plant. Highest yield cultivars (Slaney and Anna) had the highest tuber number per plant. This result is consistent with the result of Tekalign and Hammes (2005).

Leaf chl: Leaf chl measured at one week interval are presented in Table 3. Leaf chl reading taken on 27th June were significantly affected by $\mathrm{N}$ rate and cultivars while after a 4th July it was significantly affected by $\mathrm{N}$ rate. Nitrogen rate $\times$ cultivar interaction was not significant for leaf chl. Leaf chl was increased with increasing $\mathrm{N}$ rate applied. There was a significant linear relationship $\left(\mathrm{r}^{2}=0.90\right)$ between nitrogen rate applied and leaf chl (Figs 1, 2). Thse significant relationship were reported by Zebarth et al. (2002). There was a decline in leaf chl in time. This result was consistent with leaf N decrease with time by other workers (Jarrel and Beverly 1981, Güler and Güzel 1999). Rodrigues (2005) found a linear equation (chl reading $=-0.463 \mathrm{DAE}+64.400$; 
$\mathrm{r}^{2}=0.93$ ) between day after emergence (DAE) and chl reading units which indicates that chl declines with plant age. Potato cultivars used in the study differed in chl reading like observed many other workers (Bavec and Bavec 2001, Güler et al. 2006).

Table 2. Mean tuber weight and tuber number per plant of potato under different $\mathrm{N}$-doses.

\begin{tabular}{|c|c|c|c|c|c|}
\hline \multirow[t]{2}{*}{ Cultivars } & \multicolumn{5}{|c|}{$\mathrm{N}$ (kg/ha) } \\
\hline & 0 & 150 & 200 & 250 & 300 \\
\hline \multicolumn{6}{|c|}{ Mean tuber weight (g) } \\
\hline Burren & 94.5 & 89.2 & 100.9 & 103.9 & 105.4 \\
\hline Slaney & 92.5 & 97.9 & 104.8 & 104.9 & 113.5 \\
\hline Anna & 81.9 & 97.7 & 99.0 & 90.4 & 84.4 \\
\hline Emma & 98.6 & 109.3 & 92.9 & 101.7 & 105.8 \\
\hline Mean & $91.9 \mathrm{~b}$ & $98.5 \mathrm{ab}$ & $99.4 \mathrm{ab}$ & $100.2 \mathrm{ab}$ & $102.3 \mathrm{a}$ \\
\hline \multicolumn{6}{|c|}{ Tuber number per plant } \\
\hline Burren & 3.47 & 5.10 & 5.07 & 5.60 & 5.50 \\
\hline Slaney & 6.23 & 5.60 & 7.00 & 7.67 & 7.73 \\
\hline Anna & 3.93 & 8.33 & 9.90 & 7.93 & 7.07 \\
\hline Emma & 3.03 & 4.60 & 5.03 & 5.60 & 6.23 \\
\hline Mean & $4.17 \mathrm{~b}$ & $5.91 \mathrm{a}$ & $6.75 \mathrm{a}$ & $6.70 \mathrm{a}$ & $6.63 \mathrm{a}$ \\
\hline
\end{tabular}

Level of significance: Mean tuber weight: $\mathrm{N}(\mathrm{P}<0.05)$; cultivar $(\mathrm{P}>0.05)$; $\mathrm{N}$ vs cultivar $(\mathrm{P}>0.05)$; Tuber number per plant: $\mathrm{N}(\mathrm{P}<0.01)$; cultivar $(\mathrm{P}<0.01)$; $\mathrm{N}$ vs cultivar $(\mathrm{P}<0.01)$

Table 3. Leaf chlorophyll reading value of potato cultivars at different $\mathrm{N}$ rates.

\begin{tabular}{lccccc}
\hline Cultivars & \multicolumn{5}{c}{$\mathrm{N}(\mathrm{kg} / \mathrm{ha})$} \\
\cline { 2 - 5 } & 0 & 150 & 200 & 250 & 300 \\
\hline Leaf chl on 27.06.2006 & & & & \\
Burren & 46.63 & 53.23 & 51.80 & 53.50 & 53.13 \\
Slaney & 49.10 & 52.60 & 54.47 & 53.43 & 54.47 \\
Anna & 50.17 & 53.03 & 55.57 & 53.67 & 58.07 \\
Emma & 50.28 & 54.93 & 55.13 & 54.03 & 57.03 \\
Mean & $49.04 \mathrm{c}$ & $53.45 \mathrm{~b}$ & $54.24 \mathrm{ab}$ & $53.66 \mathrm{ab}$ & $55.67 \mathrm{a}$ \\
Leaf chl on 04.07.2006 & & & & \\
Burren & 46.57 & 50.70 & 50.53 & 51.83 & 54.03 \\
Slaney & 46.43 & 50.57 & 54.00 & 52.30 & 58.10 \\
Anna & 46.00 & 53.67 & 52.63 & 51.03 & 55.33 \\
Emma & 47.47 & 52.80 & 51.93 & 52.70 & 54.43 \\
Mean & $46.62 \mathrm{c}$ & 51.93 & $52.27 \mathrm{~b}$ & $51.97 \mathrm{~b}$ & $55.48 \mathrm{a}$ \\
\hline
\end{tabular}

Level of significance: Leaf chl reading for 27th June: $\mathrm{N}(\mathrm{P}<0.01)$; cultivar $(\mathrm{P}<0.01)$; N vs cultivar $(\mathrm{P}>0.05)$; Leaf chl reading for 04th July: $\mathrm{N}(\mathrm{P}<0.01)$; cultivar $(\mathrm{P}>0.05)$; $\mathrm{N}$ vs cultivar $(\mathrm{P}>0.05)$

Correlations among yield, yield attributes and leaf chl: Correlations among investigated characters relating to total yield, mean tuber weight, tuber number per plant and leaf chl are presented in Table 4. Except for a few characters (second class yield $\times$ mean tuber weight; third class yield $\times$ mean tuber weight; mean tuber weight $\times$ tuber number per plant; mean tuber weight $\times$ leaf chl measured on 27th June) there were significant correlations among the investigated characters. Leaf chl measured on 04th July showed highly significant correlations with other characteristics measured. First class tuber yield significantly correlated with leaf chl measured on 27th June ( $\mathrm{r}=0.447)$ and on 04th July $(\mathrm{r}=0.563)$. Total yield also significantly correlated with leaf 
chl measured ( $\mathrm{r}=0.492$ for June, $\mathrm{r}=0.541$ for July). This result might be attributed to the nitrogen affecting plant growth and yield. Parvizi et al. (2004) working with maize found that there was a highly significant correlation between chl reading and dry matter yield. In the present study, there were highly significant correlations between first class yield and total yield $(\mathrm{r}=0.916)$, total yield and tuber number per plant ( $\mathrm{r}=0.929)$.
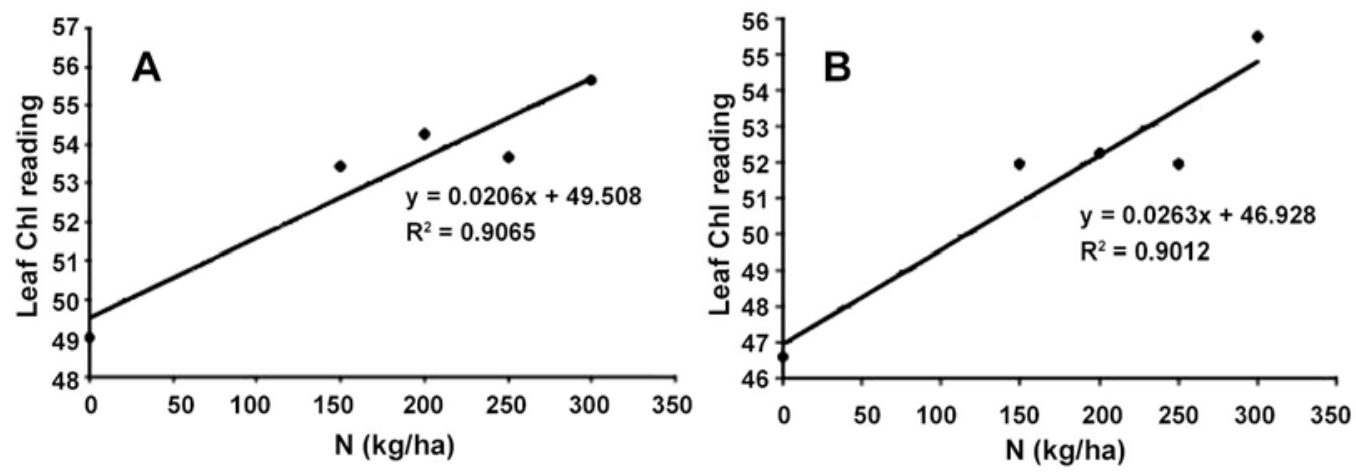

Fig. 1A-B: Relationship between nitrogen applied and leaf chl reading of potato on 27 June 2006 (A) and on 04 July 2006 (B).

Table 4. Correlation coefficients among yield, yield attributes and leaf chlorophyll reading.

\begin{tabular}{|c|c|c|c|c|c|c|c|c|}
\hline Parameters & FCY & SCY & TCY & TY & MTW & TNPP & Chl 1 & Chl 2 \\
\hline FCY & - & $0.603 * * *$ & $0.549 * * *$ & $0.916^{* * *}$ & $0.565 * * *$ & $0.772 * * *$ & $0.447 * * *$ & $0.563 * * *$ \\
\hline SCY & & - & $0.488 * * *$ & $0.791^{* * *}$ & $0.229^{\mathrm{ns}}$ & $0.761^{* * *}$ & $0.364 * *$ & $0.342 * *$ \\
\hline TCY & & & - & $0.779 * * *$ & $-0.053^{\mathrm{ns}}$ & $0.832 * * *$ & $0.411^{* *}$ & $0.382 * *$ \\
\hline TY & & & & - & $0.365^{* *}$ & $0.929 * * *$ & $0.492 * * *$ & $0.541^{* * *}$ \\
\hline MTW & & & & & - & $0.089^{\mathrm{ns}}$ & $0.200^{\mathrm{ns}}$ & $0.334 * *$ \\
\hline TNPP & & & & & & - & $0.407 * *$ & $0.463 * * *$ \\
\hline Chl 1 & & & & & & & - & $0.704 * * *$ \\
\hline Chl 2 & & & & & & & & - \\
\hline
\end{tabular}

FCY: first class yield; SCY: second class yield; TCY: third class yield; TY: total yield; MTW: mean tuber weight; TNPP: tuber number per plant; Chl 1: leaf chl reading measured on 27 June 2006; Chl 2: leaf chl reading measured on 04 July 2006.

All parameters in relation to total yield, mean tuber weight, tuber number per plant and leaf chl of potato were influenced by nitrogen rate applied and cultivar used. Slaney and Anna cultivars produced 50\% higher tuber compared to Burren and Emma cultivars. When compared to nitrogen rate for total yield it was found that at $200 \mathrm{~kg} \mathrm{~N} / \mathrm{ha}$ maximum yield was obtained. Leaf chl was significantly correlated with the all investigated characters.

\section{References}

Bavec F. and M. Bavec. 2001. Chlorophyll meter readings of winter wheat cultivars and grain yield prediction. Comm. Soil Sci. Plant Anal. 32(17-18): 2709-2719.

Blackmer T.M. and J.S. Schepers. 1995. Use of chlorophyll meter to monitor nitrogen status and schedule fertilization for corn. J. Prod. Agric. 8(1): 56-60.

Chapman H.D. and P.F. Pratt. 1961. Methods of analysis for soils, plants and waters. Division of Agricultural Science, Univ. California, California. 
Denuit J.P., M. Olivier, M.J. Goffaux, J.L. Herman, J.P. Goffart, J.P. Destain and M. Frankinet. 2002. Management of nitrogen fertilization of winter wheat and potato crops using chlorophyll meter for crop nitrogen status assessment. Agron. 22: 847-853.

Gilbert F.A. 1949. Mineral nutrition of plants and animals. Univ. Oklahoma Press, Oklahoma. 135 pp.

Güler S. and N. Güzel. 1999. Effect of varying level of nitrogen and potassium concentration in the nutrient solution on the yield and leaf composition of drip-fertilized tomatoes. Acta Hort. 506: 81-85.

Güler S., I. Macit, A. Koç and H. Ibrikci. 2006. Estimating leaf nitrogen status of strawberry by using chlorophyll meter reading. J. Biol. Sci. 6(6): 1011-1016.

Jackson M.L. 1962. Soil chemical analysis. Prentice Hall, New York.

Jarrel W.M. and R.B. Beverly. 1981. The dilution effect in plant nutrition studies. Advances Agron. 34: 197222.

Jenkins P.D. and D.G. Nelson. 1992. Aspects of nitrogen fertilizer rate on tuber dry-matter content of potato cV. Record. Potato Res. 35(2): 127-132.

Kleinkopf G.E., D.T. Westermannn and R.B. Dwelle. 1981. Dry matter production and nitrogen utilization by six potato cultivars. Agron. J. 73: 799-802.

Madeira A.C., A. Ferreira, A. de Varennes and M.I. Vieira. 2003. SPAD meter versus tristimulus colorimeter to estimate chlorophyll content and leaf color in sweet pepper. Comm. Soil Sci. Plant Anal. 34(17-18): 2461-2470.

Maier N.A., A.P. Dahlenburg and C.M.J. Williams. 1994. Effects of nitrogen, phosphorus and potassium on yield, specific gravity, crisp colour and tuber-chemical composition of potato (Solanum tuberosum L.) cv. Kennebec. Aust. J. Exptal. Agric. 34: 813-824.

Olsen S.R., C.V. Vole, F.S. Watanabe and A. Dean. 1954. Estimation of available phosphorus in soils by extraction with sodium bicarbonate. USDA Circular No. 939, Washington D.C.

Parvizi Y., A. Ronaghi, M. Maftoun and N.A. Karimian. 2004. Growth, nutrient status and chlorophyll meter readings in wheat as affected by nitrogen and manganese. Comm. Soil Sci. Plant Anal. 35(9-10): 1387-1399.

Piekielek W.P., R.H. Fox, J.D.Toth and K.E. Macneal. 1995. Use of a chlorophyll meter at the early dent stage of corn to evaluate nitrogen sufficiency. Agron. J. 87: 403-408.

Richards L.A. 1954. Diagnosis and Improvement of Saline and alkali soils. Agricultural Handbook No. 60. U.S.D.A. Washington

Rodrigues M.A. 2005. Establishment of continuous critical levels for indices of plant and presidedress soil nitrogen status in the potato crop. Comm. Soil Sci. Plant Anal. 35(13-14): 2067-2085.

Saluzzo J.A., H.E. Echeverria, F.H. Andrade and M. Huarte. 1999. Nitrogen nutrition of potato cultivars differing in maturity. J Agron. Crop Sci. 183: 157-165.

Shaaban M.M. and A.A. El-Bendary. 1999. Evaluation of nitrogen status for snap bean, potatoes and cucumber under field conditions using a portable chlorophyll meter. Alexandria J. Agric. Res. 44(1): 191-200.

Singh B., Y. Singh, J.K. Ladha, K.F. Bronson, V. Balasubramanian, J. Singh and C.S. Khind. 2002. Chlorophyll-meter and leaf color chart-based nitrogen management for rice and wheat in northwestern India. Agron. J. 94: 821-829.

Tekalign T. and P.S. Hammes. 2005. Growth and productivity of potato as influenced by cultivar and reproductive growth. II. Growth analysis, tuber yield and quality. Scientia Hort. 105: 29-44.

Tisdale S.L. and W.L. Nelson. 1956. Soil fertility and fertilizers. MacMillan, NY. 430 pp.

Turner F.T. and M.F. Jund. 1991. Chlorophyll meter to predict nitrogen topdress requirement for semidwarf rice. Agron. J. 83: 926-928.

Varvel G.E., J.S. Schepers and D.D. Francis. 1997. Chlorophyll meter and stalk nitrate techniques as complementary indices for residual nitrogen. J. Prod. Agric. 10: 147-151.

Vos J. and M. Bom. 1993. Hand-held chlorophyll meter: a promising tool to assess the nitrogen status of potato foliage. Potato Res. 36: 301-308. 
Westermannn D.T. and G.E. Kleinkopf. 1985. Nitrogen requirements of potatoes. Agron. J. 77: 616-621.

Westermannn D.T., G.E. Kleinkopf and L.K. Porter. 1988. Nitrogen fertilizer efficiencies of potatoes. Am. Potato J. 65: 377-386.

Wu J., D. Wang, C.J. Rosen and M.E. Bauer. 2007. Comparison of petiole nitrate concentrations, SPAD chlorophyll readings and QuickBird satellite imagery in detecting nitrogen status of potato canopies. Field Crop Res. 101(1): 96-103.

Yadava U.L. 1986. Rapid and nondestructive method to determine chlorophyll in intact leaves. Hort. Sci. 21(6): 1449-1450.

Zebarth B.J., M.Younie, J.M. Paul and S. Bittman. 2002. Evaluation of leaf chlorophyll index making fertilizer nitrogen recommendations for silage corn in a high fertility environment. Comm. Soil Sci. Plant Anal. 33(5-6): 665-684.

(Manuscript received on 27 October, 2008; revised on 12 November, 2009) 